\title{
Distribution of Siluriformes in a river under the influence of a small hydroelectric power plant of the Paraná River Basin, Brazil
}

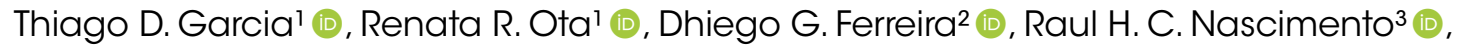 \\ Bruno A. Galindo² (1), Larissa S. Pereira ${ }^{4}$ (1) \& Augusto S. Zanatta ${ }^{2}$ (1)
}

\author{
1. Programa de Pós-Graduação em Ecologia de Ambientes Aquáticos Continentais, Universidade Estadual de Maringá. Av. Colombo, 5790, $87020-900$ \\ Maringá, PR, Brazil. (thiago.deruza@hotmail.com; renata_ota@yahoo.com.br) \\ 2. Departamento de Ciências Biológicas, Universidade Estadual do Norte do Paraná, UENP, Av. Portugal, 340, 86300-000 Cornélio Procópio, PR, Brazil. \\ (dhiegouenp@gmail.com; bruno@uenp.edu.br; zanatta@uenp.edu.br) \\ 3. Departamento de Biologia Animal e Vegetal, Universidade Estadual de Londrina, Rodovia Celso Garcia Cid. Pr, 445 Km 38, $86057-970$ Londrina, PR, Brazil. \\ (rauluenp@gmail.com) \\ 4.PDE-CAPES at the Department of Wildlife and Fisheries Sciences, Texas A\&M University, 534 John Kimbrough Blvd TAMU 2258, College Station, TX 77843, U.S.A. \\ (visiting scholar). (lari.strictar@gmail.com)
}

Received 18 January 2019

Accepted 29 October 2019

Published 16 March 2020

DOI 10.1590/1678-4766e2020005

\begin{abstract}
When a river is dammed, impacts differ according to distance from the dam under consideration, and sites closer to the dam are more affected than distant ones. Damming a river changes the flow and landscape characteristics, which, in turn, change the hydrological, limnological and ecological dynamics, such as biological production, species distribution, and ecosystem structuring, functioning and services. This study evaluates the distribution pattern of the Siluriformes (catfish) fish species near a small hydroelectric power plant in the Jaguariaíva River, considering three distinct distances from the dam: upstream region, reservoir and downstream region. Samples were taken with gillnets between March 2013 and December 2014. The abundance and richness of the Siluriformes species were evaluated. A permutational multivariate analysis of variance was used to access possible differences in species composition among sites. Finally, a permutational analysis of multivariate dispersion was used to assess possible differences among sampling sites and to examine composition similarities among sites. A total of 840 Siluriformes individuals were captured, distributed among ten species and four families. The highest richness was observed in the downstream region, while the lowest richness was observed in the reservoir area. Differences in the abundance of species were observed between the three distinct regions; the downstream region presented the highest species abundance (CPUE), whereas the lowest abundance was observed in the dam region. Hypostomus paulinus and Hypostomus strigaticeps were abundant species, but exclusively sampled in the downstream region, while Corydoras ehrhardti and Cambeva diabola presented their highest abundance in the upstream region. The distinct longitudinal distribution of Siluriformes observed in this study can be interpreted as indicative of the negative effects of damming. Our study suggests that building small dams may result in negative impacts on the fish assemblage, impacts comparable to those of large reservoirs in terms of spatial changes. It is fundamentally necessary to better evaluate the environmental impacts of small dams in the Neotropical region, especially because few is known about them and how such impacts are comparable to impacts of larger reservoirs.
\end{abstract}

KEYWORDS. fish assemblage, ichthyofauna, catfish, Paraná basin, reservoir.

RESUMO. Distribuição de Siluriformes em um rio sob influência de uma Pequena Central Hidrelétrica da Bacia do Rio Paraná, Brasil. Quando uma barragem é construída, seus impactos diferem de acordo com a distância relativa da barragem, sendo que os locais mais próximos da barragem são mais afetados que os mais distantes. $\mathrm{O}$ barramento de um rio resulta em modificações no fluxo do rio e características da paisagem, modificando sua dinâmica hidrológica, limnológica e ecológica, como produção biológica, distribuição de espécies e estruturação do ecossistema e suas funções. O padrão de distribuição de Siluriformes (bagres) no rio Jaguariaíva foi avaliado, considerando três distâncias da barragem: montante, reservatório e jusante. As amostragens foram realizadas em três regiões distintas do rio Jaguariaíva considerando a distância em relação à barragem, entre março de 2013 e dezembro de 2014, com redes de espera, e as distintas zonas originadas pelo represamento do rio. A abundância e riqueza de espécies foram avaliadas. Um total de 840 indivíduos de Siluriformes foi capturado, distribuídos em dez espécies e quatro famílias. A maior riqueza foi observada na região a jusante do reservatório, enquanto a menor foi verificada na região da barragem. Diferenças significativas na abundância das espécies entre as três regiões foram observadas; a região a jusante do reservatório apresentou a maior abundância (CPUE), enquanto a menor abundância foi observada na região do reservatório. Hypostomus paulinus e Hypostomus strigaticeps foram abundantes e exclusivamente amostrados na região a jusante do reservatório, enquanto Corydoras ehrhardti e Cambeva diabola apresentaram maiores abundâncias na região a montante do reservatório. A distribuição longitudinal de Siluriformes observada pode ser interpretada como um efeito negativo do represamento. Resultados obtidos indicam que os impactos negativos na ictiofauna, consequentes da construção de pequenas barragens podem ser comparáveis aos impactos originados pela construção de grandes barragens. É necessário avaliar os impactos da construção de pequenas barragens na região Neotropical, pois pouco se sabe acerca desses impactos e como estes são comparáveis a grandes reservatórios.

PALAVRAS-CHAVE. Assembleia de peixes, ictiofauna, bagres, bacia do Paraná, reservatório. 
Rivers and streams are currently under threat from constant exposure to several negative anthropic impacts, especially increasing dam construction, which is becoming a component of aquatic ecosystems in the main freshwater basins around the world (WINEMILLER et al., 2016). Damming a river (most often for hydropower generation) creates many environmental impacts, mainly on river flow and landscape, and changing the hydrological, limnological and ecological dynamics, such as biological production, species distribution, and ecosystem structure, functioning and services (TUNDISI \& MATSUMURA-TUNDISI, 2003). As a consequence of damming, the resulting impacts differ in relation to the distance of the dam as follows: (i) the upstream region (usually the region with less pronounced impacts) suffers habitat fragmentation, which, in the case of fish, blocks the access of populations, directly influencing genetic flow (AgOSTINHO et al., 2007); (ii) in the dam region, there is deposition of solid particles, which increases the concentration of dissolved gases and causes changes in water temperature and transparency, thermic stratification and permanent flooding of wetlands (Agostinho, 1992); (iii) the downstream region experiences reduced levels of solid particles in the water column (as these are deposited in the reservoir lake), changes in the natural flow of the river, blockage of migratory routes and loss of water quality (AGostinHo, 1992; AgostinHo et al., 2007). Even though the upstream region is usually expected to be the least affected by damming (Agostinho et al., 2007), damming still seems to affect species abundance in such regions (Pereira \& Agostinho, 2019), because dams potentially change the distribution of energy resources within the impounded area, as well as in its unimpounded reaches (MIRANDA et al., 2019). Such changes will result in a longitudinal gradient with three markedly distinct regions riverine (upstream reaches), transition and lacustrine zone of the reservoir downstream, which differ in species composition and functional groups (VelHo et al., 2001; LiN et al., 2018). In longitudinal reservoir zonation, species distributions are influenced by the range of environmental factors (MEE et al., 2018). Consequently, variation in species composition between regions (beta diversity) is expected to occur (BECKER et al., 2016; Melo et al., 2018). A decrease in both abundance and species richness would then be expected from the riverine to the lacustrine region (OLIVEIRA et al., 2010; VAŠEKA et al., 2016).

The presence of a dam can act as an environmental filter, and few fish species are capable of surviving or reproducing in this kind of environment (Dias et al., 2005; Agostinho et al., 2007, 2008; SAntos et al., 2017; NobiLE et al., 2019). The community is, therefore, restructured with new functional groups and novel interactions among species (HaHn et al., 1998; Agostinho et al., 2008). Assemblage of fish in dammed rivers results from the restructuring processes of previous species pool (FERNANDO \& HoLČíK, 1991; AgostinHo et al., 2016). Some species initially benefit from damming, mainly due to increased incorporation of allochthonous material in the environment (e.g., PEREIRA \& AgostinHo, 2019). These species generally have greater adaptive capacity, flexible feeding and high reproduction potential, presenting increased abundance right after damming (Agostinho et al., 2016; Pereira et al., 2016; Pereira \& Agostinho, 2019). However, damming seems to negatively affect even these opportunistic species in the long-term, one consequence of which is reduced abundance as these species endeavor to sustain their populations in this novel environment (Pereira \& Agostinho, 2019).

Conserving undammed rivers is a good strategy for maintaining high levels of species diversity (AFFONSO et al., 2015; WinEMILLER et al., 2016; MARQUES et al., 2018) as such tributaries are of fundamental importance to the ichthyofauna, serving as spawning and nursery areas for migratory fish (BAUMGARTNER et al., 2004; FERNANDES et al., 2009; GUBIANI et al., 2010). They also provide shelter for several sedentary species, some of which are rare, endemic or even novel to science (Volkmer-Ribeiro \& Parolin, 2010; Dei Tós, 2014). For example, a new species of Striped Raphael catfish (Platydoras birindellii Sousa, Chaves, Akama, Zuanon \& Sabaj, 2018) has recently been described (Sousa et al., 2018). This species appears to be endemic to the Xingu River where it is commonly found in rapids. However, it is absent from regions closer to the Belo Monte dam (Sousa et al., 2018).

Siluriformes are an excellent subject for an investigation into the diversity and composition of freshwater systems because dams cause a reduction in water flow (Agostinho et al., 2007) and most of this species live in running water environments (OliveIRA et al., 2010; PAGOTTO et al., 2011). Species from this order are, therefore, likely to be particularly impacted by the transformation from a lotic to a lentic environment. Ecologically, such order is extremely diverse presenting a large variety of morphological traits (PAGotTo et al., 2011). To examine the changes caused by dams, several studies of freshwater drainage systems have been carried out around the world to gain a better understanding of the influence of these constructions on the fish community (AgostinHo et al., 1997; LANGEANI et al., 2007; Miranda et al., 2008; WineMILLER et al., 2016; BANERJEE et al., 2017; LIN et. al., 2018). However, studies of small hydroelectric power plants (SHPs) have shown that such small impoundments might present different patterns from those usually observed in large dams (BAUMGARTNER et al., 2018).

SHPs present a small reservoir (maximum $13 \mathrm{~km}^{2}$ ) that function under a daily regulation or "run-of-the-river" mode, presenting a maximum potency of $30 \mathrm{MW}$ (Resolution $\mathrm{n}^{\circ} 394$ of December 04 ${ }^{\text {th }}, 1998$, ANEEL - Agência Nacional de Energia Elétrica), due to its smaller water storage capacity the SHPs have the potential to regulate seasonality. In Brazil, SHPs are built in sites closer to waterfalls and, because of their mode of operation, SHPs do not store water as large reservoirs being unable to function in dry periods (CANDIANI et al., 2013). SHPs are easy to approve, implement, and operate than larger reservoirs and, adding with their smaller dimensions and considered lesser socioeconomic impacts they usually present more advantages than larger reservoirs (BORGES \& MEIRA, 2017). On the other side, impacts caused 
by SHPs will depend majorly from the type of SHP, mode of operation, and mainly on the original characteristics of the river before damming, considering the regional relevance to migratory, endemic, and threatened species (A. A. Agostinho, Pers. commun.) However, it is a naive belief that smaller reservoirs generate fewer impacts than larger ones (BAUMGARTNER et al., 2018).

Considering that, in Brazil, SHPs are numerically more dominant than large reservoirs (425 SHPs in operation, 28 under construction and 102 approved for construction; PEREIRA et al., 2017; ANEEL, 2019), it is of great importance to understand the damming effects of SHPs on fish distribution patterns, especially when considering that damming impacts studies are usually focused on larger enterprises, while studies relying on possible impacts of smaller enterprises are misrepresented. In this context, the present study aimed to understand how Siluriformes respond to damming, investigating the longitudinal distribution of Siluriformes species in the Jaguariaíva River, in a section under the direct influence of a SHP.

\section{MATERIALS AND METHODS}

The Nova Jaguariaíva SHP $\left(24^{\circ} 18^{\prime} 7.1^{\prime}\right.$ 'S, $49^{\circ} 41^{\prime} 40.5^{\prime \prime} \mathrm{W}$ ) belongs to the Itararé River Basin and is located in a canyon $6 \mathrm{~km}$ long in the Parque Estadual Vale do Codó, where the Jaguariaíva River flows into the Paraná River basin (Fig. 1). This SHP, which started its operation in 1950, has a reservoir with a lake area of approximately 44 ha and a drainage area of $753 \mathrm{~km}^{2}$. The Jaguariaíva River is located in the morphostructural unit of the Paraná sedimentary basin. The relief of the direct area of influence is characterized by the presence of a deep canyon, with slopes of approximately 100 meters between the upper plateau and the bottom. The declivity on its edges is much accentuated, favoring the occurrence of large vertical walls that vertically reach the reservoir margin.

Samplings were performed quarterly (from March 2013 to December 2014) with gill nets (eight nets; 2.0, 4.0, $8.0,10.0,12.0,16.0$ and $18.0 \mathrm{~cm}$ mesh sizes with opposite knots) in three different regions of the Jaguariaíva River: (i) the upstream region (located above the Nova Jaguariaiva SHP reservoir), with lotic characteristics, a low depth (average to $2.0 \mathrm{~m}$ ) and substratum composed mainly of sand; (ii) the reservoir area (the most lentic region), presenting a high water depth (average to $25 \mathrm{~m}$ ) and transparency (average to $1.2 \mathrm{~m}$ ); and (iii) the downstream area (below the Nova Jaguariaíva SHP reservoir), characterized by lotic regions and a rocky bottom with predominantly shallow areas (average to $1.5 \mathrm{~m}$ ). The gillnets were set at $4.00 \mathrm{pm}$ and removed at $7.00 \mathrm{am}$ the following day. Sampled fish were anesthetized (benzocaine 10\%), fixed in formalin $10 \%$ and then preserved in ethanol $(70 \%)$. In the laboratory, fishes were identified at species level following ОтА et al. (2018) and other specific literature whenever necessary. Samplings of the ichthyofauna were carried out with permission (authorization reference

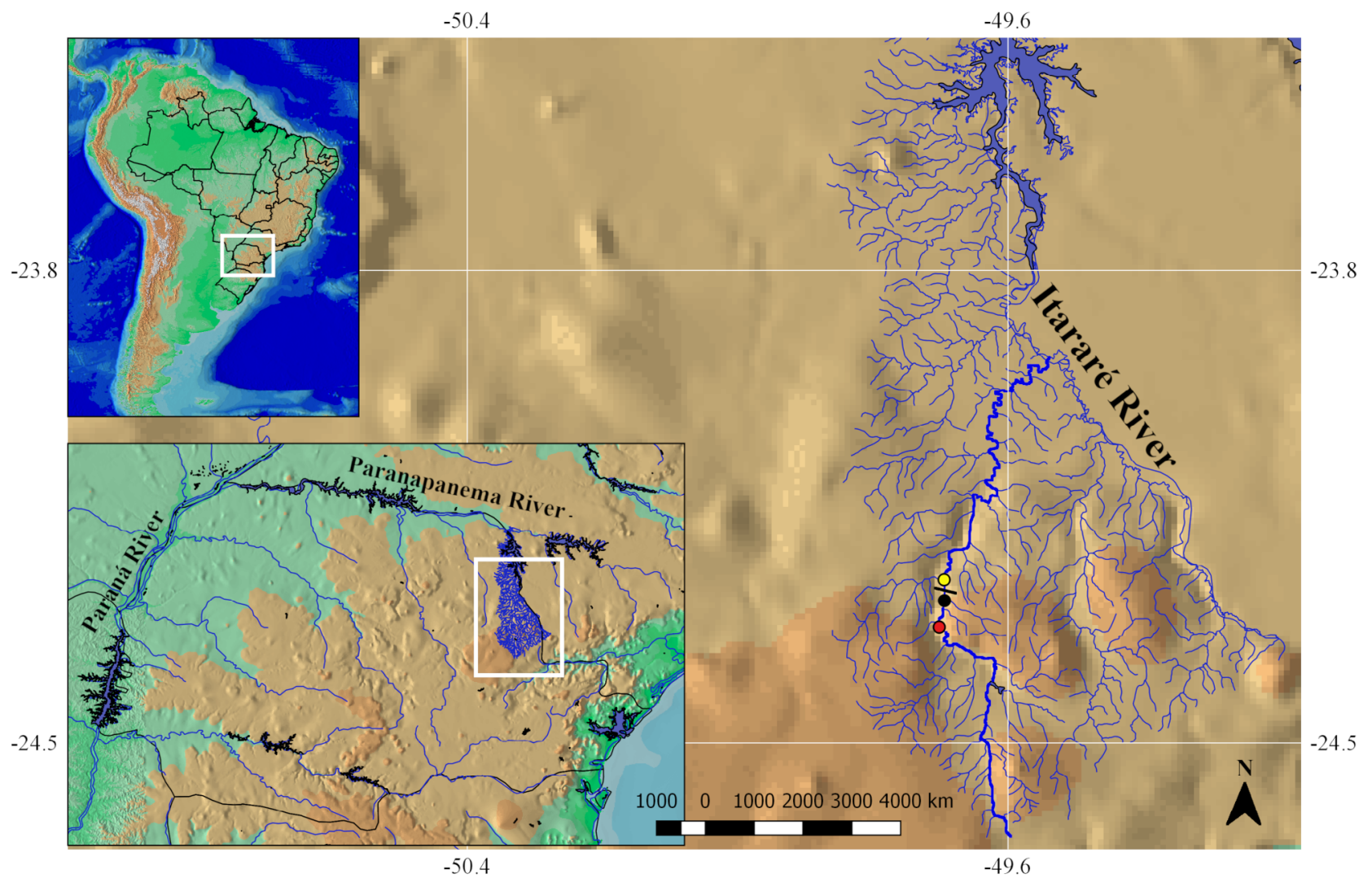

Fig. 1. Location of sampling sites in the Jaguariaiva River, Upper Parana River basin, Brazil: PCH Nova Jaguariaíva (bar); upstream (red circle); reservoir (black circle); downstream (yellow circle). 
MMA/ICMBio/SISBIO \#38202-1). Vouchers of all species were deposited in the Museu de Zoologia of the Universidade Estadual de Londrina (Tab. I).

Data analysis. Fish abundance was expressed as catch-per-unit-effort (CPUE), estimated by the number of individuals $/ 1,000 \mathrm{~m}^{2}$ net $/ 16 \mathrm{~h}$. Possible differences in species abundance and composition among sampling sites were evaluated through a permutational multivariate analysis of variance $(9,999$ permutations; PERMANOVA; ANDERSON et al., 2008). The PERMANOVA was followed by Wilcoxon tests in order to check for pairwise differences within sites. Additionally, a permutational analysis of multivariate dispersion (PERMDISP; ANDERSON 2004, 2006) was used to assess possible differences among sampling sites and to examine composition similarities among sites. This analysis measures the distance between each individual and the group multivariate median. It also determines any differences in distance in the spatial median between groups (a measure of beta diversity; ANDERSON, 2006; ANDERSON et al., 2006). The probability values used to determine significant differences in the dispersion of the multivariate space between and within sites were calculated by permutation of residuals (9,999 permutations). Post hoc pairwise comparisons were performed using permutation tests based on a pairwise t-test of the dispersion of different group combinations $(9,999$ permutations). The original data matrix containing species abundance data was $\log$-transformed $[\log (\mathrm{x}+1)]$ to reduce the influence of extreme values and was then transformed into a dissimilarity matrix by the Bray-Curtis method (BRAY \& CURTIS, 1957). Statistical analyses were performed using the "vegan" package (OKSANEN et al., 2018) in the R software for statistical computing and graphics (R CORE TEAM, 2017).

\section{RESULTS}

A total of 840 individuals of Siluriformes were captured and distributed among four families and ten species (Tab. I). The most representative family in terms of the number of species was found to be Loricariidae $(76.3 \%$ of the species sampled), followed by Callichthyidae ( $15.9 \%$ of the species sampled). Heptapteridae was the least representative ( $0.8 \%$ of the species sampled). Four species were exclusively observed within a single region: Hypostomus paulinus (Ihering, 1905), Hypostomus strigaticeps (Regan, 1908) and Neoplecostomus selenae Zawadzki, Pavanelli \& Langeani, 2008 were exclusively observed in the downstream region, while Cambeva diabola (Bockmann, Casatti \& Pinna, 2004) was observed only in the upstream region. On the other hand, Hypostomus ancistroides (Ihering, 1911) and Rhamdia quelen (Quoy \& Gaimard, 1824) were registered at all the sampled sites (Tab. I).

The greatest species richness was recorded downstream (nine species), whereas only two species were recorded at the reservoir (the lowest number of all the sampling sites). These two species registered at the reservoir were also recorded at the other sampling sites. An intermediate number of species was observed upstream, with seven species in total.

In general, the greatest species abundance (CPUE) was observed downstream, while the lowest species abundance of all sites was observed at the reservoir. The upstream site indicated intermediate abundances comparing with the reservoir and the downstream site (Fig. 2). There were significant differences in species composition and abundance among sites (PERMANOVA: $\mathrm{F}_{p(2,18)}=11.13$, $\mathrm{p}$ $<0.001$ ), with all sites differing one from the other (Wilcox

Tab. I. Capture per unit effort (unit: $\mathrm{n}^{\mathrm{o}}$ individuals $/ 1,000 \mathrm{~m}^{2}$ net/16 hours) of Siluriformes captured in the Jaguariaíva River, Upper Parana River basin, between 2013 and 2014. (-) indicates absence.

\begin{tabular}{|c|c|c|c|c|}
\hline CLASSIFICATION & Upstream & Reservoir & Downstream & Voucher \\
\hline \multicolumn{5}{|l|}{ SILURIFORMES } \\
\hline \multicolumn{5}{|l|}{ Callichthyidae } \\
\hline Corydoras ehrhardti Steindachner, 1910 & 107 & - & 5 & MZUEL 19418 \\
\hline \multicolumn{5}{|l|}{ Loricariidae } \\
\hline Hypostomus albopunctatus (Regan, 1908) & - & - & 21 & MZUEL 1941S \\
\hline Hypostomus ancistroides (Ihering, 1911) & 18 & 5 & 45 & MZUEL 19420 \\
\hline Hypostomus hermanni (Ihering, 1905) & 15 & - & 93 & MZUEL 19421 \\
\hline Hypostomus paulinus (Ihering, 1905) & - & - & 139 & MZUEL 19422 \\
\hline Hypostomus strigaticeps (Regan, 1908) & - & - & 106 & MZUEL 19423 \\
\hline Neoplecostomus selenae Zawadzki, Pavanelli \& Langeani, 2008 & - & - & 5 & MZUEL 19424 \\
\hline \multicolumn{5}{|l|}{ Heptapteridae } \\
\hline Rhamdia quelen (Quoy, Gaimard, 1824) & 5 & 7 & 5 & MZUEL 19427 \\
\hline \multicolumn{5}{|l|}{ Trichomycteridae } \\
\hline Trichomycterus candidus (Miranda Ribeiro, 1949) & 13 & - & 36 & MZUEL 19428 \\
\hline Cambeva diabola (Bockmann, Casatti \& de Pinna, 2004) & 57 & - & - & MZUEL 19430 \\
\hline
\end{tabular}


test: Downstream vs Reservoir: $\mathrm{W}=8784, \mathrm{p}<0.001$; Downstream vs. Upstream: $\mathrm{W}=7873, \mathrm{p}<0.001$; Reservoir vs. Upstream: $\mathrm{W}=5333, \mathrm{p}<0.001)$. These differences were a result of the presence of Hypostomus paulinus and $H$. strigaticeps, the most abundant species, found exclusively downstream; as well as Corydoras ehrhardti Steindachner, 1910 and C. diabola at the upstream (Fig. 3). Nevertheless, the PERMDISP did not detect significant differences among the three groups $\left(\mathrm{F}_{\mathrm{m}(18,2)}=0.80, \mathrm{p}=0.46\right.$, where the subscript " $m$ " refers to spatial medians). The dispersions were smaller in the downstream site and larger in the upstream site (average distance to median: downstream $=0.19$; reservoir $=0.28$; upstream $=0.36)($ Fig. 4).

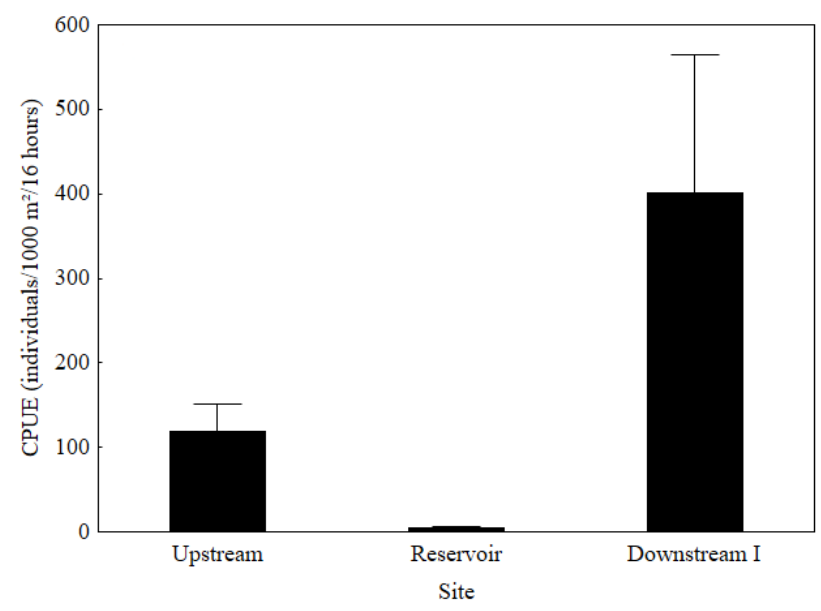

Fig. 2. Mean total abundance of Siluriformes from the Jaguariaiva River, Upper Parana River basin by site [capture-per-unit-effort (CPUE); unit: number of individuals $/ 1,000 \mathrm{~m}^{2}$ of nets $\left./ 16 \mathrm{~h}\right]$. Vertical bars = standard error.

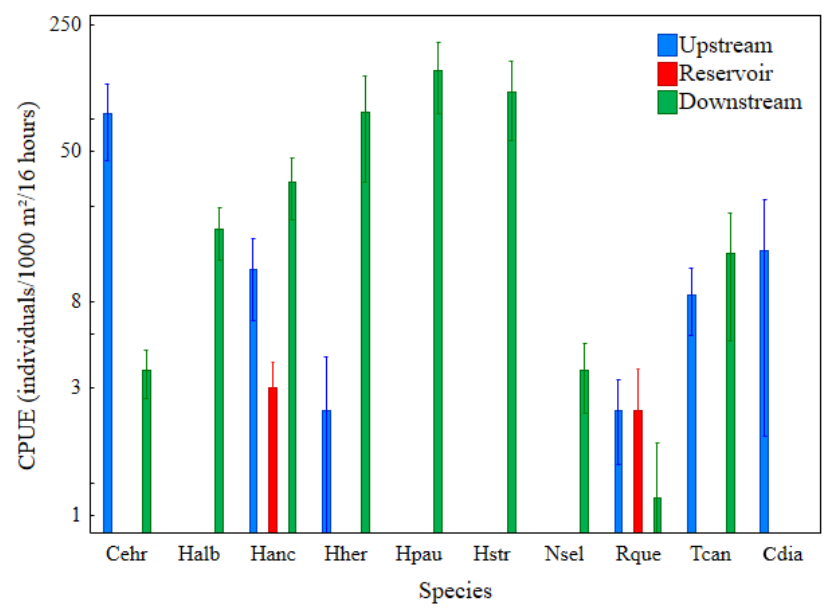

Fig. 3. Mean abundance of the Siluriformes species from the Jaguariaiva River, Upper Parana River basin by site [capture-per-unit-effort (CPUE); unit: number of individuals $/ 1,000 \mathrm{~m}^{2}$ of nets $\left./ 16 \mathrm{~h}\right]$. Vertical bars $=$ standard error (Cher, Corydoras ehrhardti; Halb, Hypostomus albopunctatus; Hanc, Hypostomus ancistroides; Hher, Hypostomus hermanni; Hpau, Hypostomus paulinus; Hstr, Hypostomus strigaticeps; Nsel, Neoplecostomus selenae; Rque, Rhamdia quelen; Tcan, Trichomycterus candidus; Cdia, Cambeva diabola).

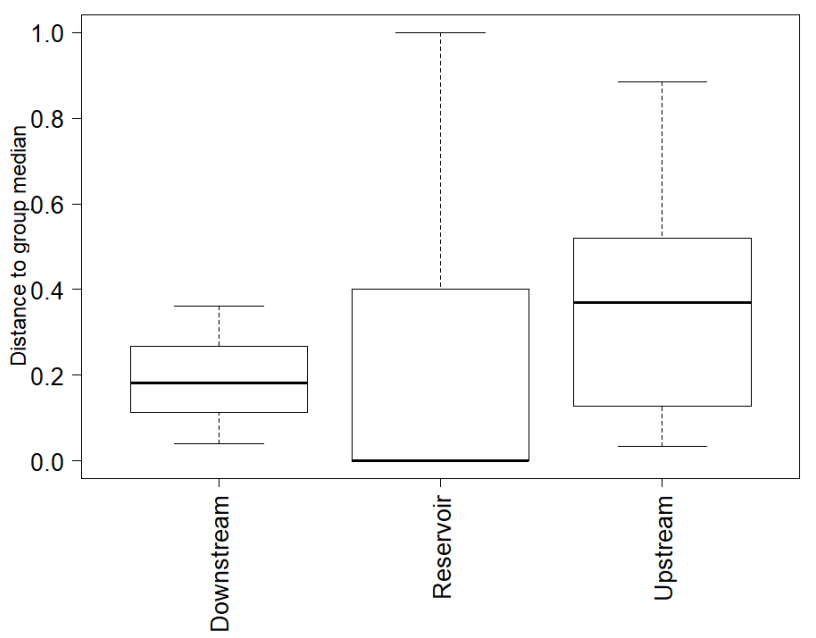

Fig. 4. Variations in composition of Siluriformes in the three distinct zones in the Nova Jaguaraiva River under the effects of damming. Species richness (beta diversity) was assessed as species dispersion within the three zones using permutational analysis of multivariate dispersions (PERMDISP; e.g., a greater distance to the spatial median indicates a larger dispersion and, therefore, broader beta diversity). The upper and lower hinges correspond to the $25^{\text {th }}$ and $75^{\text {th }}$ quartiles, respectively.

\section{DISCUSSION}

The diversity of Siluriformes presented dissimilarities in longitudinal distribution in the area under the influence of the Nova Jaguariaíva SHP. The richness of Siluriformes recorded was relatively lower to those already observed in other studies of reservoirs, for example, 18 Siluriformes species in six hydroelectric reservoirs in the Paraná State (LuIz et al., 2003) and 22 in the Capivara Reservoir whose dam crosses the Paranapanema River (Hoffmann et al., 2005). However, the Jaguariaíva River is relatively smaller than the aforementioned rivers and, since there are no previous studies of its ichthyofauna, it is impossible to state whether the relatively low richness recorded is an effect of species extirpation due to damming or a natural condition of the river itself.

Differences between species composition among studied sites emphasize a high spatial heterogeneity, pattern expected for small and medium-sized rivers (OliveIRA \& LACERDA, 2004; GonÇALVES \& BRAGA, 2008). This is related mostly to differences in species composition in each site, as species proportional abundances remained relatively low for most of the sampled species. The longitudinal distribution observed for Siluriformes differed from that generally observed in large reservoirs in which the reservoir and downstream regions are the most affected, presenting fewer species than upstream (AgostinHo et al., 2007). This difference in species richness might be a characteristic intrinsic from the studied environment. The downstream site presented higher species richness when compared to the other sites (upstream and reservoir), showing that it may be the preferred region of Loricariidae. The most 
abundant species (Hypostomus albopunctatus, H. hermanni, H. paulinus, H. strigaticeps and Neoplecostomus selenae) were exclusively observed in this region. The preference of these species for this site probably relates to their rheophilic character, being rarely observed in dammed areas and, when observed, presenting low abundances (BENNEMANN et al., 1995; CeCILIO et al., 1997). In the reservoir site, it is possible that the preexisting species pool of the river, characteristics of lotic environments, do not develop well in the dammed area, presenting a poorer species richness and abundance. The upstream area, expected to be the least affected (Agostinho et al., 2008; Pereira et al., 2016), presented intermediate diversity of fish when compared to the reservoir and downstream sections. The presence of dams in the main tributaries of the Upper Paraná River has been considered as one of the main causes of the absence of large migratory species (AgostinHo et al., 1999). This is because the reservoirs act as physical barriers, obstructing the flow of migratory fish downstream and upstream of the rivers (Katopodis \& Williams, 2012; Pelicice et al., 2015; AgostinHo et al., 2016).

As formation of a dam creates a clear zonation, that is, the presence of distinct areas (e.g., upstream, a reservoir area and downstream) with distinct and peculiar characteristics (Cunha, 1995; Agostinho et al., 2007), this is probably the origin of the longitudinal differences in species richness and distribution observed in this study. However, we note that there were no data prior to damming, and even though damming is probably the major cause of the observed process, other factors may also explain these patterns, such as resource availability (HAHN \& FUGI, 2007), interactions between species, and the physical and structural characteristics of the sites (TAYLOR et al., 1996). Additionally, the observed pattern may not only be a result of a single factor, but the combination of several factors, including the ones already mentioned, with damming effects (WARD \& STANFORD, 1983; THORTON et al., 1990; AgOSTINHO et al., 2008).

In general, most of the diagnosed species were not registered in the area of the reservoir as such area is not a favorable habitat for them, including the characteristics of a deep, lentic environment and distant margin (e.g., SABINO \& CASTRO, 1990; AgostinHo et al., 2007). Species in the reservoir area, such as $R$. quelen, may be present due to their high environmental and trophic plasticity (LuIz et al., 2003). On the other hand, the high abundance of $H$. ancistroides downstream may have been favored by the presence of rock blocks and the turbulent environment rather than sandy bottom backwaters. This species has frequently been observed becoming a dominant species after impoundments due to its high plasticity and tolerance to environmental condition, being specially observed in flowing and rocky bottom waters (Uieda, 1984; Garavello \& Garavello , 2004; PerezJUNIOR \& GARAVELlO, 2007).

Most species in reservoirs seek lateral tributaries or lotic areas for reproduction, but the presence of a dam restricts or even eliminates species' access to fluvial regions (ANGULO-VALENCIA et al., 2016). The presence of the dam in this study probably reduced the connectivity of the river, promoting segregation of the fish assemblages and restricting them in different areas. At the studied sites, under the influence of the Nova Jaguariaíva SHP, it was observed that distinct communities are being constituted. The longitudinal distribution pattern of fish assemblage in the SHP may, therefore, have been influenced by the presence of the dam. Although the physical impacts of SHPs are generally considered to be smaller for most of the ichthyofauna, the biological impacts on the ichthyologic community may be extremely high for several species, mainly those less adapted to lentic conditions or with smaller plasticity, resulting in significative changes in species composition, abundance and richness. This highlights the fact that potential impacts of building small dams are actually comparable to those of large reservoirs in terms of spatial changes (BAUMGARTNER et al., 2018). Our study highlights the need to consider how small reservoirs impact the environment and, consequently, the fish assemblages as one of the main focuses for new research and conservation in fluvial systems in South America, especially because SHPs are numerous and few is known about whether their impacts are comparable to those of larger reservoirs.

Acknowledgments. We are thankful to Dr. Angelo A. Agostinho for assistance. We are grateful to the Companhia Paranaense de Energia for financing the project. We also thank the Universidade Estadual do Norte do Paraná (UENP) for its infrastructure and logistic support, and the Universidade Estadual de Londrina (MZUEL) for hosting the voucher specimens. We are grateful to the Fundação Araucária for granting TD a scholarship and to the Conselho Nacional de Desenvolvimento Científico e Tecnológico (CNPq) for granting RRO a scholarship. LSP is supported by PDE-CAPES (Proc. 88881.170373/2018-01).

\section{REFERENCES}

Affonso, I. P.; Azevedo, R. F.; Santos, N. L. C.; Dias, R. M.; Agostinho, A. A. \& Gomes, L. C. 2015. Pulling the plug: Strategies to preclude expansion of dams in Brazilian rivers with high priority for conservation. Natureza \& Conservação 13:199-203.

AgostinHo, A. A. 1992. Considerações sobre os impactos dos represamentos na ictiofauna e medidas para sua atenuação. Um estudo de caso: Reservatório de ITAIPU. Revista da Unimar 14:89-107.

Agostinho, A. A.; Bini, L. M. \& Gomes, L. C. 1997. Ecologia de comunidades de peixes da área de influência do reservatório de Segredo. In: Agostinho, A. A. \& Gomes, L. C. eds. Reservatório de Segredo: bases ecológicas para o manejo. Maringá, EDUEM, p. 97-111.

Agostinho, A. A.; Gomes, L. C. \& Pelicice, F. M. 2007. Ecologia e manejo de recursos pesqueiros em reservatórios do Brasil. Maringá, EDUEM. 501p.

Agostinho, A. A.; Gomes, L. C.; Santos, N. L. C.; Ortega, J. C. \& Pelicice, F. M. 2016. Fish assemblages in Neotropical reservoirs: Colonization patterns, impacts and management. Fisheries Research 173:26-36.

Agostinho, A. A.; Miranda, L. E.; Bini, L. M.; Gomes, L. C.; Thomaz, S. M. \& Suzuki, H. I. 1999. Patterns of colonization in Neotropical reservoirs, and prognoses on aging. In: Tundisi, J. G. \& Milan, S. eds. Theoretical reservoir ecology and its applications. São Carlos, International Institute of Ecology, Brazilian Academy of Sciences, Backhuys, p. 227-264.

Agostinho, A. A.; Pelicice, F. M. \& Gomes, L. C. 2008. Dams and the fish fauna of the Neotropical region: impacts and management related to diversity and fisheries. Brazilian Journal of Biology 68:1119-1132.

ANDERSON, M. J. 2004. PERMDISP: a FORTRAN computer program for permutational analysis of multivariate dispersions (for any 
two-factor ANOVA design) using permutation tests. Auckland, University of Auckland. 11p.

ANDERSON, M. J. 2006. Distance-based tests for homogeneity of multivariate dispersions. Biometrics 62:245-253.

Anderson, M. J.; Ellingsen, K. E. \& MCardle, B. H. 2006. Multivariate dispersion as a measure of beta diversity. Ecology Letters 9:683-693.

Anderson, M. J.; Gorley, R. N. \& Clarke, K. R. 2008. PERMANOVA + for PRIMER: Guide to Software and Statistical Methods. PRIMER-E. Plymouth, UK

Aneel - Agência Nacional De Energia Elétrica (Brasil). 2019. Banco de Informações de Geração: BIG. Disponível em: <http://www2.aneel. gov.br/aplicacoes/capacidadebrasil/capacidadebrasil.cfm $>$. Accessed October $30^{\text {th }}, 2019$

Angulo-Valencia, M. A.; Agostinho, A. A.; Suzuki, H. I.; LuzAgostinho, K. D. D. \& Agostinho, C. S. 2016. Impoundments affect fish reproduction regardless of reproductive strategy. Lakes and Reservoirs 21:362-374.

BANERJeE, M.; MukHERJEe, J. \& RAY, S. 2017. A review on reservoir system and its ecology in Indian perspective. Proceedings of the Zoological Society 70:5-20.

Baumgartner, G.; Nakatani, K.; Gomes, L. C.; Bialetzki, A. \& Sanches, P. V. 2004. Identification of spawning sites and natural nurseries of fishes in the upper Paraná River, Brazil. Environmental Biology of Fishes 71:115-125.

Baumgartner, M. T.; Baumgartner, G. \& Gomes, L. C. 2018. Spatial and temporal variations in fish assemblage: testing the zonation concept in small reservoirs. Brazilian Journal of Biology 78(3):487-500.

Becker, B.; Galhardo, B. D. O. S.; Macedo, D. R.; Hughes, R. M.; Callisto, M. \& Santos, G. B. 2016. Influence of limnological zones on the spatial distribution of fish assemblages in three Brazilian reservoirs. Journal of Limnology 75:156-168.

Bennemann, S. T.; Silva-Souza, A. T. \& Rocha, G. R. A. 1995. Composicion ictiofaunisticaen cinco localidades de la cuenca del Rio Tibagi, PR Brasil. Interciencia 20:7-13.

Borges, R. R. \& MeIRA, R. L. 2017. Impactos Socioambientais de Pequenas Centrais Hidrelétricas e Estudo de Caso PCH-Queluz-SP e LavrinhasSP no Rio Paraíba do Sul. Cadernos UniFOA 4:23-35.

Bray, J. R. \& CURTIS, J. T. 1957. An ordination of the upland forest community of southern Wisconsin. Ecology Monographs 27:325-349.

Candiani, G.; Camargo-Penteado, C. L.; De Souza, E. C. C. B.; Dos Santos, E. M. \& Biondi, A. E. C. 2013. Estudo de caso: aspectos socioambientais da pequena central hidrelétrica ( $\mathrm{PCH}$-Queluz-SP, na bacia do rio Paraíba do Sul. Revista do Departamento de Geografia 25:98-119.

Cecilio, E. B.; Agostinho, A. A.; Júlio-Júnior, H. F. \& Pavanelli, C. S. 1997. Colonização ictiofaunística do reservatório de Itaipu e áreas adjacentes. Revista Brasileira de Zoologia 14:1-14.

CunHA, S. B. 1995. Impactos das Obras de Engenharia Sobre o Ambiente Biofísico da Bacia do Rio São João (Rio de Janeiro - Brasil). Rio de Janeiro, Editora do Instituto de Geociências. 415p.

Dei Tós, C. 2014. Variation of the ichthyofauna along the Goioerê River: an important tributary of the Piquiri-Paraná Basin. Iheringia, Série Zoologia 104:104-112.

Dias, R. M.; Bailly, D.; Antônio, R. R.; Suzuki, H. I. \& Agostinho, A. A. 2005 Colonization of the Corumbá Reservoir (Corumbá River, Paraná River Basin, Goiás State, Brazil) by the "lambari" Astyanax altiparanae (Tetragonopterinae; Characidae). Brazilian Archives of Biology and Technology 48:467-476.

Fernandes, R.; Agostinho, A. A.; Ferreira, E. A.; Pavanelli, C. S.; SuzuKi, H. I.; Lima, D. P. \& Gomes, L. C. 2009. Effects of the hydrological regime on the ichthyofauna of riverine environments of the Upper Paraná River floodplain. Brazilian Journal of Biology 69:669-680.

Fernando, C.; \& HoLČík J. 1991. Fish in Reservoirs. Internationale Revue der gesamten Hydrobiologie und Hydrographie 76:149-167.

Garavello, J. C. \& Garavello, J. P. 2004. Spatial distribution and interaction of four species of the catfish genus Hypostomus Lacépède with bottom of Rio São Francisco, Canindé do São Francisco, Sergipe, Brazil (Pisces, Loricariidae, Hypostominae). Brazilian Journal of Biology 64:591-598.
GONÇALVES, C. S. \& BRAGA, F. M. S. 2008. Fish diversity and occurrence in the influence area of the Mogi Guaçu reservoir and oxbow lakes, high Paraná river basin, São Paulo, Brazil. Biota Neotropica 8:103-114.

Gubiani, E. A.; Gomes, L. C.; Agostinho, A. A. \& Baumgartner, G. 2010. Variations in fish assemblages in a tributary of the upper Paraná River, Brazil: A comparison between pre and post-closure phases of dams. River Research and Applications 26:848-865.

Hahn, N. S.; Agostinho, A. A.; Gomes, L. C. \& BinI, L. M. 1998. Estrutura trófica da ictiofauna do reservatório de Itaipu (Paraná-Brasil) nos Primeiros Anos de sua Formação. Interciencia 23:299-305.

HaHN, N. S. \& FugI, R. 2007. Alimentação de peixes em reservatórios brasileiros: alterações e consequências nos estágios iniciais do represamento. Oecologia Brasiliensis 11:469-480.

Hoffmann, A. C.; Orsi, M. L. \& ShibatTa, O. A. 2005. Diversidade de peixes do reservatório da UHE Escola Engenharia Mackenzie (Capivara), Rio Paranapanema, bacia do alto rio Paraná, Brasil, e a importância dos grandes tributários na sua manutenção. Iheringia, Série Zoologia 95:319-325.

Katopodis, C. \& Williams, J. G. 2012. The development of fish passage research in a historical context. Ecological Engineering 48:08-18.

Langeani, F.; Castro, R. M. C.; Oyakawa, O. T.; Shibatta, O. A.; Pavanelli, C. S. \& CASATTI, L. 2007. Diversidade da ictiofauna do Alto Rio Paraná: composição atual e perspectivas futuras. Biota Neotropica 7:181-197.

Lin, P.; GaO, X.; LiU, F.; LI, M. \& Liv, H. 2018. Long-term monitoring revealed fish assemblage zonation in the Three Gorges Reservoir. Journal of Oceanology and Limnology 37:1-10.

Luiz, E. A.; Gomes, L. C.; Agostinho, A. A. \& Bulla, C. K. 2003. Influência de processos locais e regionais nas assembleias de peixes em reservatórios do Estado do Paraná, Brasil. Acta Scientiarum, Biological Sciences 25:107-114.

Marques, H.; Dias, J. H. P, Perbiche-Neves G.; Kashiwaqui, E. A. L. \& RAmos, I. P. 2018. Importance of dam-free tributaries for conserving fish biodiversity in Neotropical reservoirs. Biological Conservation 224:347-354

Mee, J. A.; Robins, G. L. \& Post, J. R. 2018. Patterns of fish species distributions replicated across three parallel rivers suggest biotic zonation in response to a longitudinal temperature gradient. Ecology of Freshwater Fish 27:44-61.

Melo, S. M.; Pinha, G. D.; Ragonha, F. H.; Fontes-Junior, H. M. \& TAKEDA, A. M. 2018. Reservoir longitudinal gradient promotes ordered losses on diversity and density of Ephemeroptera community. Brazilian Journal of Biology 78:785-792.

Miranda, L. E.; Granzotti, R. V. \& DembKowski, D. J. 2019. Gradients in fish feeding guilds along a reservoir cascade. Aquatic Sciences 81:1-11.

Miranda, L. E.; Habrat, M. D. \& Miyazono, S. 2008. Longitudinal gradients along a reservoir cascade. Transactions of the American Fisheries Society 137:1851-1865.

Nobile, A. B.; Freitas-Souza, D.; Lima, F. P.; Queiroz, J.; Bayona-Perez, I. L.; Carvalho, E. D. \& Ramos, I. P. 2019. Damming and seasonality as modulators of fish community structure in a small tributary. Ecology Freshwater Fish 28(4):563-572.

Oksanen, J.; Blanchet, F. G.; Friendly, M.; Kindt, R.; Legendre, P.; Mcglinn, D.; Minchin, P. R.; O’hara, R. B.; Simpson, G. L.; Solymos, P.; Stevens, M. H. H.; Szoecs, E. \& Wagner, H. 2018. Vegan: Community Ecology Package.

Oliveira, E. F.; Goulart, E.; Breda, L.; Minte-Vera, C. V.; De Paiva, L. R. S. \& Vismara, M. R. 2010. Ecomorphological patterns of the fish assemblage in a tropical floodplain: Effects of trophic, spatial and phylogenetic structures. Neotropical Ichthyology 8(3):569-586.

OliveirA, J. C. \& LACERDA, A. K. G. 2004. Alterações na composição e distribuição longitudinal da ictiofauna na área de influência do reservatório de Chapéu d'Uvas, bacia do rio Paraíba do Sul (MG), pouco depois da sua implantação. Revista Brasileira de Zoociências 6:45-60.

Ota, R. R.; Deprá, G. D. C.; GraÇa, W. J. D. \& Pavanelli, C. S. 2018. Peixes da planície de inundação do alto rio Paraná e áreas adjacentes: revised, annotated and updated. Neotropical Ichthyology 16(2):e170094.

Pagotto, J. P. A.; Goulart, E.; Oliveira, E. F. \& Yamamura, C. B. 2011. Trophic ecomorphology of Siluriformes (Pisces, Osteichthyes) from a tropical stream. Brazilian Journal of Biology 71:269-279. 
Pelicice, F. M.; Pompeu, P. S. \& Agostinho, A. A. 2015. Large reservoirs as ecological barriers to downstream movements of Neotropical migratory fish. Fish and Fisheries 16(4):697-715.

Pereira, L. S. \& Agostinho A. A. 2019. Do advantages in resource exploration lead to better body condition? Environmental Biology of Fishes 112:997-1008.

Pereira, L. S.; Delariva, R. L. \& Agostinho, A. A. 2016. Effects of river damming in Neotropical piscivorous and omnivorous fish: feeding, body condition and abundances. Neotropical Ichthyology 14:267-278.

Pereira, L. S.; Neves, R. D. A. F.; Miyahira, I. C.; Kozlowsky-Suzuki, B.; Branco, C. W. C.; De Paula, J. C. \& Dos Santos, L. N. 2017. Nonnative species in reservoirs: how are we doing in Brazil? Hydrobiologia 817:71-84.

Perez-Junior, O. R., \& Garavello, J. C. 2007. Ictiofauna do ribeirão do Pântano, afluente do rio Mogi-Guaçu, bacia do alto rio Paraná, São Paulo, Brasil. Iheringia, Série Zoologia 97(3):328-335.

R Core TeAm. 2017. R: A Language and Environment for Statistical Computing. Vienna, R Foundation for Statistical Computing. Available at $<$ http://www.R-project.org $>$.

SAbino, J. \& CAStro, R. M. C. 1990. Alimentação, período de atividade e distribuição espacial dos peixes de um riacho da Floresta Atlântica (Sudeste do Brasil). Revista Brasileira de Biologia 50:23-36.

Santos, N. C. L.; De Santana, H. S.; Ortega, J. C. G.; Dias, R. M.; Stegmann, L. F.; Araújo, I. M. S.; Severi, W.; Bini, L. M.; Gomes, L. C. \& Agostinho, A. A. 2017. Environmental filters predict the trait composition of fish communities in reservoir cascades. Hydrobiologia 802:245-253.

Sousa, L. M.; Chaves, M. S.; Akama, A.; Zuanon, J. \& Sabaj, M. H. 2018. Platydoras birindellii, new species of striped raphael catfish (Siluriformes: Doradidae) from the Xingu Basin, Brazil. Proceedings of the Academy of Natural Sciences of Philadelphia 166:1-13.

Taylor, C. M.; Winston, M. R. \& Matthews, W. J. 1996. Temporal variation in tributary and mainstream fish assemblages in a Great Plains stream system. Copeia 2:280-289.

Thorton, K. W.; Kimmel, B. L. \& Payne, F. E. 1990. Reservoir limnology: ecological perspectives. New Jersey, John Wiley \& Sons. 256p.
Tundisi, J. G. \& Matsumura-TundisI, T. 2003. Integration of research and management in optimizing multiple uses of reservoirs: the experience in South America and Brazilian case studies. Hydrobiologia 500:231-242.

UiEDA, V. S. 1984. Ocorrência e distribuição dos peixes em um riacho de água doce. Revista Brasileira de Biologia 44(2):203-213.

Vašeka, M.; Prchalováa, M.; RínaA, M. Blabolila P. Čecha, M.; DraštíKa, M.; FrouzováA, J.; JŮZaA, T.; Kratochvíla, M.; MuŠKaA, M.; PeterkaA, J.; SAJdlováa, Z.; ŠmeJKala, M.; TuŠERA, M.; VeJŘíKA, L.; Znachora, P.; MrkvičKaAb, T.; SeĎAa J. \& KubeČKaA, J. 2016. Fish community response to the longitudinal environmental gradient in Czech deep-valley reservoirs: Implications for ecological monitoring and management. Ecological Indicators 63:219-230.

Velho, L. F. M.; Lansac-Tôha, F. A.; Bonecker, C. C.; Bini, L. M. \& Rossa, D. C. 2001. The longitudinal distribution of copepods in Corumbá Reservoir, State of Goiás, Brazil. Hydrobiologia 453:385-391.

Volkmer-Ribeiro, C. \& Parolin, M. 2010. As esponjas. In: Parolin, M.; Volkmer-Ribeiro, C. \& LeANDrini, J. A. eds. Abordagem ambiental interdisciplinar em bacias hidrográficas no estado do Paraná. Campo Mourão, Editora FECILCAM, p. 105-130.

WARD, J. V. \& StANFORD, J. A. 1983. The serial discontinuity concept of lotic ecosystems. In: Fontaine, T.D. \& Bartell, S. M. eds. Dynamics of Lotic Ecosystems. Ann Arbor, Ann Arbor Science Publishers, p. 29-42.

Winemiller, K. O.; Mcintyrep, B.; Castello, L.; Fluet-Chouinard, E.; Giarrizzo, T.; Nam, S.; Baird, I. G.; Darwall, W.; Lujan, N. K.; Harrison, I.; Stiassny, M. L. J.; Silvano, R. A. M.; Fitzgerald, D. B.; Pelicice, F. M.; Agostinho, A. A.; Gomes, L. C.; Albert, J. S.; Baran, E.; Petrere-JR, M.; Zarfl, C.; Mulligan, M.; Sullivan, J. P.; Arantes, C. C.; Sousa, L. M.; Koning, A. A.; Hoeinghaus, D. J.; Sabaj, M.; Lundberg, J. G.; Armbruster, J.; Thieme, M. L.; Petry, P.; Zuanon, J.; Torrente Vilara, G.; Snoeks, J.; Ou, C.; Rainboth, W.; Pavanelli, C. S.; Akama, A.; Van Soesbergen, A. \& Sáenz, L. 2016. Balancing hydropower and biodiversity in the Amazon, Congo, and Mekong: Basin-scale planning is needed to minimize impacts in mega-diverse rivers. Science 351(6269): 128-129. 